\title{
Pulmonary hypertension in schistosomiasis mansoni
}

\author{
Hipertensão pulmonar em paciente com \\ esquistossomose mansônica
}

\section{José Roberto Lambertucci ${ }^{1}$, Vinicius Tostes Carvalho ${ }^{1}$ and Luciana Cristina dos Santos Silva ${ }^{1}$}

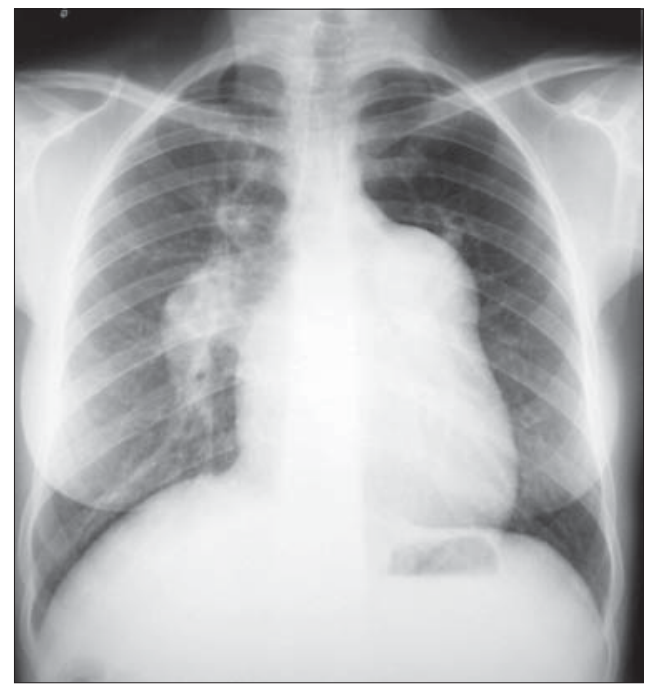

$\mathbf{A}$

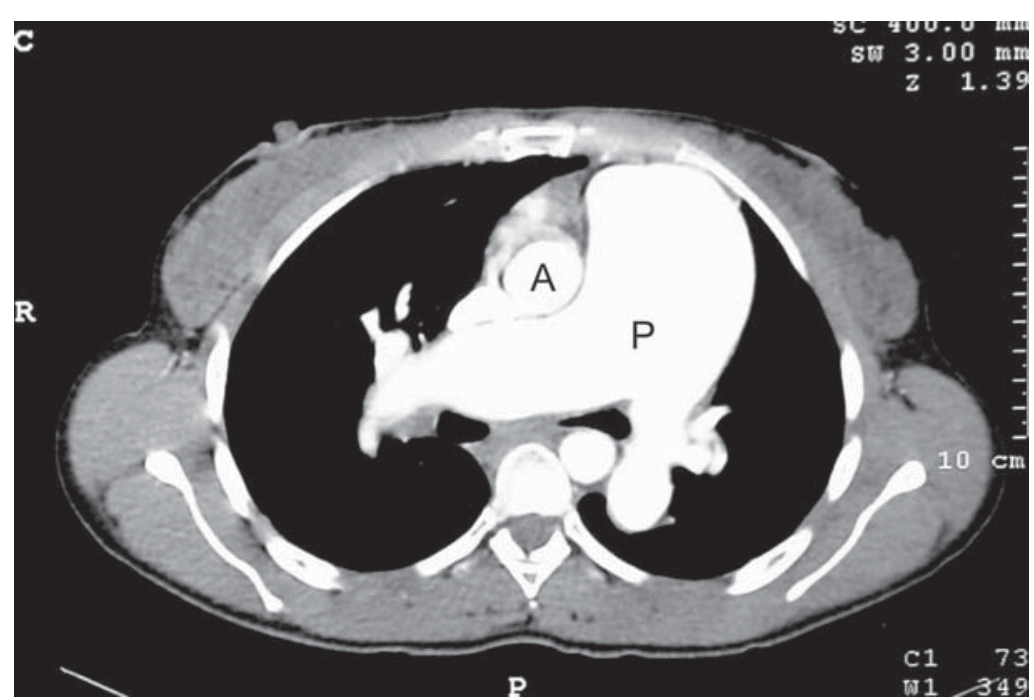

B

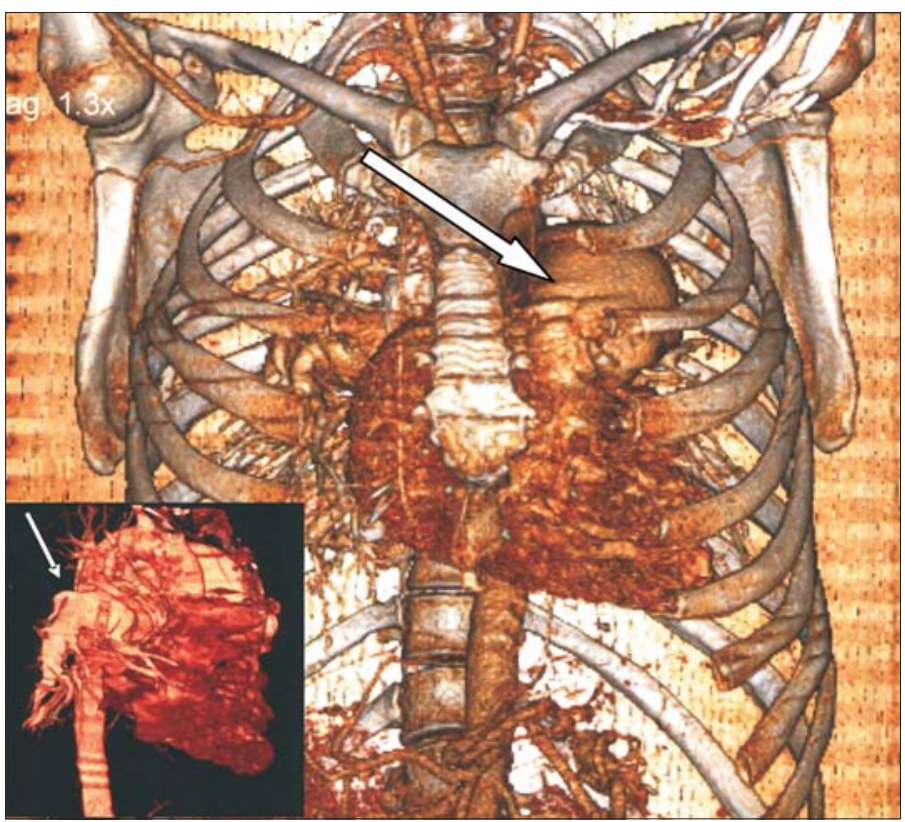

C

1. Serviço de Doenças Infecciosas e Parasitárias da Faculdade de Medicina da Universidade Federal de Minas Gerais, Belo Horizonte, MG, Brasil. Address to: Prof. José Roberto Lambertucci. Depto de Clínica Médica/FM/UFMG. Av. Alfredo Balena 190, 30130-100 Belo Horizonte, MG, Brasil e-mail: lamber@uai.com.br 
A 31-year-old woman was admitted to hospital reporting shortness of breath for 10 days. She also reported chest pain and 3 episodes of exertional syncope in the 8 months prior to examination. She had been admitted to an intensive care unit (ICU) 6 months before the present admission, with a presumptive diagnosis of pulmonary thromboembolism. Physical examination revealed increased intensity of the pulmonic component of the second heart sound, with a spleen palpable $3 \mathrm{~cm}$ below the left costal margin. Chest radiograph showed enlargement of the central pulmonary arteries (Figure A). Electrocardiogram showed right axis deviation, $\mathrm{R} / \mathrm{S}$ ratio $>1$ in lead $\mathrm{V} 1$, and increased $\mathrm{P}$ wave amplitude in lead II. Two-dimensional transthoracic echocardiography with Doppler analysis revealed a systolic pulmonary pressure of $101 \mathrm{mmHg}$. Right-sided cardiac catheterization showed a mean pulmonary pressure of $88 \mathrm{mmHg}$ and a systolic pressure of $140 \mathrm{mmHg}$. Helical CT scans were performed after intravenous contrast injection (Figure B - A = aorta; $\mathrm{P}=$ dilated pulmonary trunk). Three-dimensional reconstruction using helical CT is shown in Figure C (note the aneurismal dilation of the pulmonary artery - larger white arrow - and, in the insert, the enlargement of the right pulmonary artery). The patient has had a diagnosis of hepatosplenic schistosomiasis mansoni confirmed by ultrasound, with esophageal varices documented by upper endoscopy.

Paciente de 31 anos admitida ao hospital com queixa de dispnéia nos últimos 10 dias. Relatou ainda dor torácica e três episódios de síncope durante o esforço nos últimos oito meses. Foi admitida em centro de tratamento intensivo (CTI), há oito meses, com o diagnóstico presuntivo de tromboembolismo pulmonar. 0 exame físico revelou aumento da intensidade de $\mathrm{P} 2$ e o baço foi palpado a $3 \mathrm{~cm}$ do rebordo costal esquerdo. A radiografia do tórax mostrou dilatação das artérias pulmonares (Figura A). O eletrocardiograma mostrou desvio do eixo para a direita, R/S > 1 em V1. 0 ecocardiograma trans-torácico bi-dimensional com Doppler revelou a pressão sistólica pulmonar de $101 \mathrm{mmHg}$ (o cateterismo mostrou pressão média na artéria pulmonar de $88 \mathrm{mmHg}$; sistólica de $140 \mathrm{mmHg}$ ). A tomografia computadorizada (TC) helicoidal, após contraste intravenoso mostrou grande dilatação do tronco da pulmonar (Figura $\mathrm{B}-\mathrm{A}=$ aorta; $\mathrm{P}=$ tronco da artéria pulmonar). A reconstrução tridimensional da imagem capturada pela TC helicoidal é mostrada na Figura C (note a dilatação aneurismática do tronco da artéria pulmonar seta branca maior - e, na figura encartada, a artéria pulmonar direita). A paciente já tinha diagnóstico de esquistossomose hepatoesplênica definida em outras internações e confirmada pela ultra-sonografia; havia também varizes do esôfago na endoscopia digestiva alta.

\section{REFERENCES}

1. Barbosa MM, Lamounier JA, Oliveira EC, Souza MV, Marques DS, Silva AA, Lambertucci JR. Pulmonary hypertension in schistosomiasis mansoni. Transactions of the Royal Society of Tropical Medicine and Hygiene 90:663-665, 1996

2. Lambertucci JR, Moreira RF, Barbosa AJ. Solitary pulmonary nodule caused by Schistosoma mansoni in a patient with medullary thyroid carcinoma. Revista da Sociedade Brasileira de Medicina Tropical 38:536-537, 2005.

3. Lambertucci JR, Serufo JC, Gerspacher-Lara R, Rayes AA, Teixeira R, Nobre V, Antunes CM. Schistosoma mansoni: assessment of morbidity before and after control. Acta Tropica 77:101-109, 2000. 